\title{
Social factors outside of family and school related to student dropout ${ }^{1,2}$
}

\author{
Ivana Stepanović Ilić ${ }^{3}$ \\ University of Belgrade, Faculty of Philosophy, Institute of Psychology
}

\section{Ljiljana B. Lazarević}

University of Belgrade, Faculty of Philosophy, Institute of Psychology

\section{Nataša Simić}

University of Belgrade, Faculty of Philosophy

The paper presents a systematisation of broader social factors affecting student dropout in Serbia from the framework of Bronfenbrenner's approach. Although recognised by authors and commonly related to community and education as a system, these factors are rarely investigated. Starting from our previous research into dropout, focused primarily on family and school, this study is aimed at investigating community and systemic factors. The data were compiled by semi-structured interviews with respondents from the following groups (including relevant public statistical data): students who dropped out/are at risk and their parents; school principals and counsellors from schools with high and low attrition rates; teachers', parents' and students' representatives from schools with high dropout rates; social workers in charge of schools with a low attrition rate; representatives of national educational institutions. The findings reveal that factors with a negative impact on children's education dominate over supportive ones which could have a preventive effect on attrition. Negative influences exist in all social niches: in microsystems (peers prone to risky behaviour, poor neighbourhoods), in weak mesosystem connections of school and family with local institutions, in exosystems (undeveloped

1 The paper is part of the project "Identification, measurement and development of cognitive and emotional competences important for a society oriented towards European integrations" (No. 179018) conducted by the Institute of Psychology, Faculty of Philosophy University of Belgrade, and funded by the Ministry of Education, Science and Technological Development, Republic of Serbia and the Project "Research and analysis study of school, individual and social factors influencing primary and secondary school drop-out and identification of innovative approaches for dropout prevention in school and through community services" funded by UNICEF.

2 A small portion of the results presented in this study, within microsystem and a few in the mesosytem, was previously reported in Stepanović Ilić, Videnović \& Lazarević, 2015. 
regions), up to the macrosystem level (legislative inefficiency, lack of cooperation within educational institutions and between governmental departments). Productive features were observed in mesosystem connections of schools as examples of good practice, as well as at macrosystem level in the form of recognising the dropout problem at the national level. Although preliminary, the obtained results provide useful guidelines for future investigations.

Key words: dropout, community and systemic factors, qualitative analysis, positive and negative influences within various ecological niches

\section{Introduction}

This is an exploratory qualitative study on broader social factors influencing children dropout, analysing various data collected within a project realised in Serbia with UNICEF support. In the previous paper (Stepanović Ilić, Videnović \& Lazarević, 2015) we inspected 12 case studies including children who dropped out of school (or were at risk of doing so) and some of their parents. As elaborated there, we used Bronfenbrenner's ecological theory as the appropriate framework for the analysis of such an intricate phenomenon caused by a plurality of factors and their interrelations. Hence, that research provided insight into family, school and peers from neighbourhood as relevant microsystems in which children, who left school or are at risk of doing so, participate directly. At the mesosystem level we mainly analysed family interaction with school and, only briefly, the relationship of schools with a high attrition rate (enrolled by children from our case studies) with the local community. Exosystem analysis was focused on parents' and school staff's reflections on systems, above family and school, which indirectly influence the children from case studies. Thus, parents mainly described poverty they live in and the prejudice they are faced with, while teachers and school staff listed problems including low salaries, lack of specific training and inadequate school procedures contributing to dropout (Stepanović Ilić, Videnović \& Lazarević, 2015). Macrosystem data were again reflections of parents and school staff on the position of education in Serbian society.

The research to be presented now is a step further focused on the analysis of broader attrition factors, outside of family and school. We are particularly interested in dropout determinants which authors (De Witte et al., 2013; Dowrick\& Crespo, 2005; Lyche, 2010; Rumberger, 2011) usually mark as community factors (neighbourhood characteristics, employment opportunities, social discrimination) and as systemic factors (attrition databases, policy papers, prevention measures, networks of institutions, collaboration between educational and related ministries). Since these factors are rarely considered together and obviously difficult to inspect, 
we believe that their systematisation from an ecological perspective could represent a useful approach. In addition, these factors have rarely been examined, especially in Serbia, so a preliminary analysis of community and systematic factors introduced here will provide a useful guidance for future investigations.

\section{Earlier studies on community and systemic factors}

Surveys of dropout established that the - risk is lower in communities where peer groups consist of children motivated to learn (Herbert \& Reis, 1999; Rumberger; 1983). Early school leavers mainly socialise with those who have poor academic achievementsor who dropped out of school (BattinPearson et al., 2000; Cairns, Cairns \& Neckerman, 1989; Lee \& Ip, 2003) and are often prone to risky behaviour (Lee \& Ip, 2003). Student attrition is common in poverty-stricken communities (Rumberger, 2011). Those communities do not contain institutional (nurseries, medical centres and so on) or spare time (parks, playgrounds and different programmes) resources aimed at children (Rumberger, 1987). They are usually ghettoised, removed from urban areas, with a high unemployment rate and mostly include people of low educational levels (De Witte, et al., 2013; European Commission, 2014).Social isolation from relatives and neighbours is common, which leads to a lack of monitoring of children's activities by adult community members (Rumberger, 2011). Marginalised groups are often affected by such living conditions which together with language barriers, cultural differences, frequent relocating and exposure to prejudice additionally contribute to a high dropout rate (Bowers \& Sprott, 2012; Bynum \& Thompson, 1983; Rumberger, 2011). Described communities are usually in economically, institutionally and infrastructurally undeveloped regions with a poor availability of schools which are often remote (De Witte, et al., 2013; Periata \& Pastor, 2000; UNICEF 2014). Full-time jobs are scarce, and a large number of seasonal jobs contribute to student drop out because children have to work in order to supplement the family income (Entwisle et al., 2004).

Studies regardingthe educational system highlight the importance of cooperation between school and local institutions for preventing and reducing attrition (De Witte et al., 2013; Rumberger, 2011). A fair educational system, flexible individualised educational routes and applicable inclusion measures are vital (Hattie, 2009; the Ministry of Education, Science and Technological Development RS, Social Inclusion and Poverty Reduction Unit and UNICEF, 2014). Industrialised countries are focusing on early tracking of children at risk, data bases updating andcreating policy framework specifically targeting dropout problem with wide range measures, from prevention to suppression 
(European Commission, 2014, Rumberger 2011; De Witte \& Csillag, 2014). At a broader, governmental level, Rumberger (2011)uses the expression "collective responsibility for student learning process" as an essential factor in combating attrition. The European Commission (2014) promotes the connection between various institutions and cross-government cooperation as critical. Analysing school failure in Serbia,Rado (2010) points out the following factors, related to the Ministry of Education andthe government, contributing to a high dropout rate: lack of statistical data, schools with a high attrition are not visible and do not suffer any consequences, a weak implementation capacity of the Ministry, undeveloped policy coordination mechanisms, unclear and unstable educational priorities changing withineach government term.

\section{The aims}

This is an exploratory study aimed at identifying broader social factors of student dropout in Serbia. Starting from our previous investigation, predominantly considering school and family influences in analysis of case studies, we are making a step towards a systematisation of wider community and systemic attrition factors. In order to accomplish that goal we will quote a relatively small part of results from the previous research, expand some analyses only "sketched" there and mostly consider new relevant data. We combine framework ofBronfenbrenner's theory $(1979 ; 1994)$ withIvićs (2014) elaboration of Vygotsky's approach regarding deformative environmental influences, to grasp positive and negative community and systemic factors related to student attrition in different niches. Within a microsystem, we will just briefly refer to the results of previous research into peer relationships in neighbourhoods and community characteristics (activities and content aimed at children). The mesosystem will represent the relationships family and school establish with the local community and social services (which are in charge of dropout children). In the previous study, families' relationships with the local community and social services were not analysed. Schools' relationships with them were examined, but only in the case of schools with a high attrition rate and just from the perspective of school employees. Here, the analysis of relationships between high attrition rate schools and community/social services will be enhanced. Furthermore, these data will supplemented with the analysis of those relationships in the case of schools with a low attrition rate (as examples of good practice) in order to compare the two school types, but also to search for positive and protective community factors. Moreover, for the investigation of the relation between "good practice" schools and social services both perspectives will be considered, the perspective of the school staff and the other of employees within social service centres. At the exosystem 
level we aim to identify the features of wider surroundings (region) and its characteristics relevant for increasing/decreasing the attrition rate. In order to do that we will mainly rely on public statistical data and use a few data from the case studies which were not analysed in the previous research. At the macro level, our objective is to investigate institutions that create education policy at the national level, which was not the topic of our previous survey.

To sum up, for each ecological niche the following sources of data are used: microsystem (the results from the previous research and some data from interviews with social services staff), mesosystem (the results from theprevious research regarding the relationships between schools with a high attrition rate and the local community and social services; case studies data not analysed in the previous study; interviews with school principals, counsellors and psychologists from schools with a high dropout rate and those representing examples of good practice; interviews with social services in charge of good practice schools; focus groups with teachers, parents and students from schools with a high attrition rate), exosystem (available relevant documents and public statistical data mainly from the Statistical Office of the Republic of Serbia and The Official Gazette of the RS and data from case studies), macrosystem (interviews with representatives of educational institutions atthe national level, as well as legal documents from The Official Gazette of the Republic of Serbia).

\section{Method}

Sample. The analysis was performed on data collected in: case studies including children who drop out (or are at the risk of doing so) and some of their parents; primary schools with a high attrition rate from Serbian municipalities; primary schools representing a good practice regarding attrition and learning support; 3 social services centres in charge of "good practice schools" and 3 important national educational institutions (the Ministry of Education, Science and Technological Development, the Institute for Evaluating Education Quality and the National Education Council). Consequently the sample included respondents form the following subsamples:

a) 12 students $^{4}$ ( 8 male and 4 female)who dropped out (or are at risk) and 4 of their parents (more about this subsample see Stepanović, Videnović \& Lazarević, 2015)

4 It is important to mention that dropout was not investigated as a phenomenon related to specific student groups, although studies often relate it to particular marginalised population groups, but significantly wider. Hence schools with a high attrition rate were not mostly attended by Roma students (their numbers varied across schools), and among 12 case study pupils there were 2 Roma. 
b) School principals $(n=8)$, school counsellors and psychologists $(n=12)$ from 8 primary schools with a high attrition rate from 8 Serbian municipalities. The criteria for school selection can be found in Simić \& Krstić (2017).

c) 25 teachers, 43 students (not prone to truancy and attrition) and 22 parents (members of school's parents' board) from 8 primary schools with a high dropout rate.

d) School principals $(n=6)$, school psychologists and counsellors $(n=6)$, and 6 primary schools which are examples of good practice (low attrition rate, good functioning and learning support). Since it was not possible to select equivalent schools to those with a high dropout rate regarding the relevant criteria, the "good practice schools" were chosen at the recommendation of the Institute for Evaluating Education Quality (ZVKOV) and local education authorities.

e) Representatives of social service centres $(n=3)$ in charge of 6 primary schools which are examples of good practice.

f) Three representatives of educational institutions at the national level: the Ministry of Education, Science and Technological Development (MPNTR); the Institute for Evaluating Education Quality (ZVKOV) and the National Education Council (NPS).

Procedures and instruments. We used qualitative methodology focusing on respondents' experiences and understandings regarding the dropout phenomena in order to gain ecologically valid data.

Students prone to truancy and attrition, as well as some of their parents were investigated in 12 case studies including semi-structured interviews (Stepanović, Videnović \& Lazarević, 2015). For the purpose of our present study the following topics from the interviews were referred to or further analysed: family circumstances, cooperation with social services, relationships with neighbours, children friendships and spare time habits. Notes made by the examiners in the field regarding relevant information about a student, family, home represented an additional source of data.

Semi-structured interviews were carried out with school principals, school counsellors and psychologists in 8 schools with a high attrition rate and in 6 "good practice schools". The following topics were relevant for our present study: cooperation of families with children prone to truancy with social services, school communication with local institutions and social services regarding dropout problems, reasons for dropping out, school programmes and measures aimed at reducing student attrition, students' learning support, school values, school staff and student relationships.

When it comes to "good practice schools" semi-structured interviews were conducted with representatives of social service centres they cooperate 
with, investigating centre's practice regarding dropout children and their parents, communication with parents and schools, preventive measures, challenges.

Focus groups were realised with teachers, members of school parents' boards and student representatives in schools with a high dropout rate in order to gain their perspective of dropout problems within a school. The guidelines for discussions included the same topics as interviews for the school staff.

Semi-structured interviews with the representatives of national educational institutions focused on issues related to reliability of dropout records, influences, prevention measures and the main challenges.

\section{Results}

\section{Microsystem perspective}

Peers from neighbourhood. The previous research suggested rather problematic friendships of children who left school or are at the risk of doing so.The majority ofcase study children do not socialise with their classmates outside of school, some of them are prone to risky behaviours and usually live in dysfunctional families with weak parental supervision (Stepanović Ilić, Videnović \& Lazarević, 2015).

Community characteristics. According to our earlier findings families from the case studies live in poor neighbourhoods far away from schools with limited offer of content for children, and their houses can be described as derelict, unfinished and sparingly equipped with appliances (Stepanović Ilić, Videnović \& Lazarević, 2015). Although we talked only to social workers from 3 centres on territories of "good practice schools", they confirmed the mentioned findings stating that dropout students are most often from poor families not equipped with books, educational materials or toys that would motivate their children to learn.

\section{Mesosystem perspective}

Cooperation of family with local community and social services. Case studies do not provide a lot of data regarding the existence of these mesosystem connections. Only 1 of 4 interviewed parents mentions that the family has been visited by social services: "... they came, threatened to take my child away, and then they saw his total lack of interest for school so they gave up". Data regarding connections with the local authorities are available only in the casestudy of a 17-year old Roma boy who regularly spends time on the 
premises of the NGO which takes care of the children living on the streets. That is where he gets his meals and socialises with children and staff. The analysis of interviews for school principals and counsellors shows that there are no government-funded projects aimed at raising parents' awareness when it comes to the importance of education and capacities to foster children's schooling. Unfortunately, we did not talk to staff from social service centres in charge of schools with high attrition, but we have data from those in charge of "good practice" schools which could be informative. They claim to be understaffed, which, taking into consideration the broad scope of activities of social service centres, increases the limitations of field work with families. They also state the different measures they apply: financial support for families, procurement of educational materials, provision of school meals and transportation, raising parents' awareness regarding the importance of education, enhancing parents' competencies to help their children with school assignments. The findings do not provide an unambiguous image, but they undoubtedly indicate the shortcomings of mesosystem connections of families which are essential for successful education.

Cooperation of schools (with high attrition rates) with the local community and social services. The results from the preceding study regarding the schools with a high dropout rate indicate undeveloped mesosystem connections with local institutions (Stepanović, Videnović \& Lazarević, 2015). Additional analysis of focus group materials with teachers and interviews with the counsellor show that the most significant impact on the decrease in dropout rates was achieved by implementing a project aimed at supporting education of Roma children in one school. Remedial classes were organised and they involved Roma teaching assistants. School counsellor and teachers claim that students showed progress, had better attendance and a lower dropout rate. However, the project was discontinued after a year because the school and local authorities were unable to fund it any longer. Principals and counsellors from schools with a high attrition rate indicated that communication with social service centres is unsatisfactory, while the cooperation with other local organisations mostly exists, but that potential is underused (Stepanović, Videnović \& Lazarević, 2015).

Cooperation of "good practice" schools with the local community and social services. The image of mesosystem connections in schools which serve as examples of good practice is different. In 4 out of 6 schools the cooperation with the municipality and social service centres regarding the dropout problem is said to be good. The institutions are relatively well connected and work together on each individual case. One school counsellor says: "We have a good cooperation with the Centre, we contact them when we fail to return a child, they do the field work, speak to the parents, try in different ways... it often 
works, particularly with financial support...". In one school the cooperation is perceived as moderate, and in another one as bad. We interviewed the staff of the social service centre those schools are referred to. They claim to communicate with the said schools almost daily, which according to one social worker "... ensures coordinated action from different sides in the case of a child at risk". Still, social workers state that the cooperation could be better. They emphasise that schools should familiarise them with problematic cases earlier. Social services lack information from schools about children, their problems and family circumstances. One social service centre psychologist states that school counsellors are "overwhelmed" by administrative work and have no time, and often no human resources, to work on student attrition prevention. We were also told that the cooperation is better with schools which have teams for solving the dropout problem. These schools contact the centres more often, whereas in schools where everything comes down to individuals there are few reports since that person is reluctant to claim responsibility and submit an official request to the social service centre. Data from schools with good practice indicate a more developed cooperation network with local institutions such as municipalities, the police, medical or cultural centres. There is also cooperation with local youth offices and numerous NGOs, often included in the prevention of student attrition (financing school meals, textbooks, stationery, student transportation). Generally speaking, the cooperation between the local community and school, including collaboration with parents, represents an important albeit underused resource for supporting schools in student attrition prevention, even in cases of schools with good practices.

\section{Exosystem perspective}

Region. The analysis of available data regarding the socio-economic status of local authorities confirms the well-established findings about the high dropout level in poor regions. Five out of 8 schools with high attrition are from municipalities whose economic development is estimated as below the Republic's average ( 3 - insufficiently developed municipalities in range of $60-80 \%$ of Republic's average and 2 - devastated areas in range below $50 \%$ of the average), 1 is at the level close to Republic's average and only 2 are above (Statistical Yearbook, 2014). The greatest percentage of attrition in primary and particularly in secondary education is recorded in undeveloped municipalities - in some of them it even exceeded 30\% (The Official Gazette of the Republic of Serbia, 2013a). Poverty and unemployment contribute to an increase in migrations in search of jobs, but also to hiring children in seasonal or family jobs which drag them away from school, which was observed in 4 of 12 case studies. One 17-year old boy who completed only 
primary school says: "Mum is ill, I was afraid all the time .... In the end, I had to work and take care of mum and dad, because no one else could". Apart from that, poor availability of schools in such areas also contributes to student withdrawal from school. It has been mentioned that case studies showed it was children from remote rural areas who drop out of schools, secondary ones in particular. Besides, talks with MPNTR and social service centre representatives often emphasised the problem of poorly developed regions in eastern and southern Serbia which parents leave in order to look for work abroad to provide for their families. According to our interviewees, children from such families without parental oversight usually have difficulties in school and are prone to truancy. Moreover, our data reveal that the choice of specific vocational training within vocational schools is often out of sync with shortages in the job market. Although municipalities are authorised to plan educational profiles in accordance with local job market needs, interviewed school principals feel it hardly ever happens. Schools are, however, obliged to develop career guidance and counselling programmes (The Official Gazette of RS, 2013, article 15), but no school with a high student dropout rate in our sample has actually implemented them, nor are they recognised as student withdrawal prevention mechanisms.

\section{Macrosystem perspective}

Findings from talks with the representatives of educational institutions at the national level pointed out various problems related to treating the issue of student attrition. Deputy Education Minister claims that MPNTR has no official and accurate data regarding student dropout rate. According to him, school and local authorities' records are out of date due to unsatisfactory level of cooperation between these institutions, which could be improved by adjusting the laws in the fields of education and social care. He highlights the significance of raising awareness of the student attrition problem at the national level and its inclusion into the Education Development Strategy (The Official Gazette of RS, 2012). He adds that there are programmes aimed at improving educational conditions for marginalised groups, networking of schools with local institutions, as well as promoting parents' participation in children's education. However, the key issue according to him is that the programmes' outcomes are not monitored. The representative of the Institute for Evaluating Education Quality (ZVKOV) also talks about substandard children's records, particularly when they move from one municipality to another. She mentions problems children with special needs face when trying to remain in standard educational system, which indicates unsatisfactory inclusion policy implementation. According to her, student attrition is most 
influenced by poor realisation of standards for adjusting the curriculum to students, which does not provide sufficient or individualised support. The additional obstacle, according to her, lies in the fact that there is no systematic monitoring in schools, nor work on the problem of student attrition. She also believes that good cooperation between school psychologists on one side and the school principal on the other is the key to decreasing the dropout rate. Concordantly, we have to raise the question of the consequences of planned redundancies of school counsellors in schools with fewer than 32 classes (The Official Gazette of RS, 2015a, 2015b). The representative of the National Education Council (NPS) stresses that student attrition has recently been put under their competence, but that the mechanisms for tackling this issue systematically have not been provided: "The Council is in charge of monitoring and recommending measures, nothing more than that". In her words: "cooperation between various stakeholders addressing this issue is poor, therefore it is necessary to define how each of them participates in the process of monitoring children at the risk of dropping out of school. Clear legislation is required to appoint institutions that tackle this problem and to offer concrete step-by-step guidelines and envisage detailed procedural solutions". She believes it is wrong that student attrition and many other issues in education are under local authorities' competence. That is how in her opinion bigger and richer regions are favouredand problems of undeveloped areas become even greater: "It is not the issue of where a child lives, but should be the matter of government policing.... and therefore an equal treatment should be provided for everybody". The data obtained from interviews with the representatives of educational institutions indicate that there is recognition of this problem at the highest level, as well as that certain steps have been taken to combat it. However, there seem to be numerous flaws primarily related to vague and inadequate legislation, unsatisfactory cooperation between institutions at the national level, and the lack of collaboration between different government departments.

To sum up results of qualitative data analysis regarding dropout factors within various niches we created the following table systematising positive and negative aspects of particular surroundings. 
Table 1:A systematisation of detected positive and negative influences within different ecological niches

\begin{tabular}{|c|c|c|c|}
\hline \multicolumn{2}{|c|}{ Ecological niche } & Positive aspects/influences & Negative aspects/influences \\
\hline \multirow[b]{2}{*}{ Microsystem } & $\begin{array}{l}\text { Peers from } \\
\text { neighbourhood }\end{array}$ & & $\begin{array}{ll}- & \text { weak bonds between classmates } \\
- & \text { socialising with children prone to risky } \\
& \text { behaviour and low educational aspirations }\end{array}$ \\
\hline & Community & & $\begin{array}{ll}- & \text { insufficient monitoring by adults } \\
- & \text { poverty, lack of content aimed at children } \\
\text { - } & \text { distance from school }\end{array}$ \\
\hline \multirow[b]{2}{*}{ Mesosystem } & $\begin{array}{l}\text { Cooperation } \\
\text { of family } \\
\text { with local } \\
\text { community and } \\
\text { social services }\end{array}$ & & $\begin{array}{ll}- & \text { undeveloped/inadequate } \\
\text { - } & \text { lack of human resources in social services } \\
\text { - } & \text { families move frequently, which hinders } \\
& \text { cooperation with social services }\end{array}$ \\
\hline & $\begin{array}{l}\text { Cooperation } \\
\text { of school } \\
\text { with local } \\
\text { community and } \\
\text { social services }\end{array}$ & 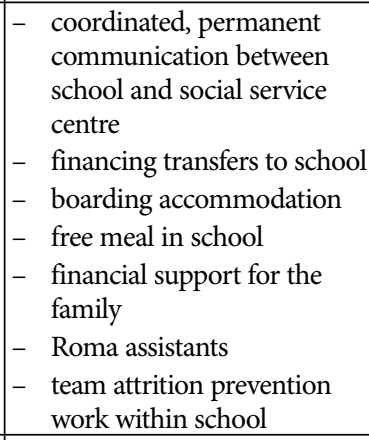 & $\begin{array}{ll}- & \text { non-existent/poor/sporadic - inadequate } \\
& \text { exchange of information and monitoring } \\
& \text { dropout children } \\
- & \text { non-existent or unsustainable projects } \\
- & \text { school counsellor service overload } \\
- & \text { lack of practical work in local companies }\end{array}$ \\
\hline Exosystem & Region & & $\begin{array}{ll}- & \text { poor/undeveloped } \\
\text { - } & \text { lack of coordination between educational } \\
& \text { profiles and shortages on the job market } \\
\text { - } & \text { lack of career guidance in schools } \\
\text { - } & \text { parents going abroad to work, which leads } \\
& \text { to discontinued education }\end{array}$ \\
\hline \multicolumn{2}{|l|}{ Macrosystem } & $\begin{array}{l}\text { student attrition in policy } \\
\text { papers } \\
\text { programmes for encouraging } \\
\text { education in children } \\
\text { from marginalised groups, } \\
\text { promoting the importance } \\
\text { of children's education } \\
\text { amongst parents and } \\
\text { networking of schools with } \\
\text { local institutions }\end{array}$ & 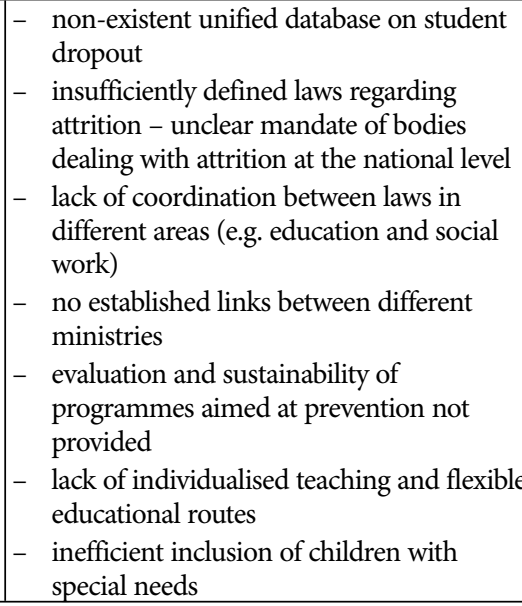 \\
\hline
\end{tabular}




\section{Discussion and conclusions}

We believe this paper has shed light on the role of broad social factors in student attrition which have not been investigated often, even though their significance was indicated in dropout studies (De Witte et al., 2013; Rumberger, 2011).Our results show that negative aspects of surroundings in Serbia are incomparably more numerous than supportive ones (see Table 1) which signals that preventive measures have to be shaped so as to transform them and/or create conditions for establishing new supporting tools.Our previous study (Stepanović, Videnović \& Lazarević, 2015) indicated that children at risk of dropping out socialise with peers prone to risky behaviours and live in poor communities as observed in other countries (De Witte et al., 2013; Lee \& Ip, 2003; Rumberger, 2011).The additional analysis of data from high attrition schools in this study suggests that even sporadic and local preventive measures at the mesosystem level seem to reduce truancy which highlights the importance of nurturing and developing relationships among microsystems towards sustainability and consequently lasting effects. The data regarding families' connections with local institutions are insufficient but still enough to indicate poor cooperation. However, in the case of schools with a high attrition rate, even in those with good practice, networking with local institutions undoubtedly has to be more systematic and regular since an efficient solution to the problem of student attrition calls for the coordination of various stakeholders (European Commission, 2014; Rado, 2010; Rumberger, 2011). Living conditions in poor regions, especially in southern and eastern Serbia, seem to affect, at least partially, the high attrition rate. Poverty and unemployment contribute to an increase in migrations in search of jobs, but also to the inclusion of children in seasonal or family jobs dragging them away from school which is also stated in foreign studies (Entwisle et al., 2004). The introduction of modern and profitable vocational trainings would be one of the solutions leading to a decrease in student attrition in these areas. That could improve the reputation of local schoolssince students would be given good quality education which would facilitate their transition to the job market. An essential prerequisite for that is a planned and sustainable cooperation at the local level between schools, local authorities, companies and the job market, which brings us back to problematic mesosystem connections. The lack of networking among national educational institutions and the absence of crossgovernment coordination are even more noticeable in our findings. Thus, it is crucial to engage professionals from various fields and establish cooperation between the Ministry of Education and other departments (employment, youth, social care, family, justice, health, economy). The importance of forming coordinative bodies to connect the aforementioned stakeholders and evaluate their work is emphasised in domestic (Ministry of Education, Science and Technology RS, Social Inclusion and Poverty Reduction Unit 
\& UNICEF, 2014) and European studies (European Commission, 2014). Although it is very important that dropout issue is one of the national priorities, macrosystem analysis shows that many flaws emphasised by Rado (2010) still exist. We could agree with him that Serbian education needs a "mainstream policy" providing applicable measures aiming at improving fairness and learning success across the entire system. A recent investigation by the Institute of Psychology (Kovač-Cerović et al., 2016) is concordant with studies stating that the most efficient measures in reducing student attrition are related to individual support and the existence of flexible education routes suitable for children with various needs and abilities (De Witte, et al., 2013; European Commission, 2014; Rumberger, 2011).

Since this study is a preliminary systematisation based on qualitative analysis of the available data, we believe in necessity of further investigations which would examine all relevant microsystems and their connections, as well as suprasystems, from an ecological perspective, which would provide a comprehensive approach to the problem of student attrition and enable creation of sustainable measures for its solution.

\section{References}

Battin-Pearson, S., Newcomb, M. D., Abbott, R. D., Hill, K. G., Catalano, R. F., \& Hawkins, J. D. (2000).Predictors of early high school dropout: A test of five theories. Journal of educational psychology, 92(3), 568-582.

Bowers, A. J. \& Sprott, R. (2012). Examining the Multiple Trajectories Associated with Dropping Out of High School: A Growth Mixture Model Analysis. The Journal of Educational Research, 105, 176-195.

Bronfenbrenner, J. (1979). The Ecology of Human Development. Cambridge, Massachusetts: Harvard University Press.

Bronfenbrenner, U. (1994). Ecological Models of Human Development. In: P. Peterson, E. Baker \& B. McGaw (Eds.). International Encyclopaedia of Education, Vol. 3, 2nd Ed (pp.37-43). Oxford: Elsevier.

Bynum, J., \& Thompson, W. (1983). Dropouts, stop outs and persisters: The effects of race and sex composition of college classes. College and University, 59(1), 39-48.

Cairns, R. B., Cairns, B. D., \& Neckerman, H. J. (1989). Early school dropout: Configurations and determinants. Child Development, 60(6),1437-1452.

De Witte, K., Cabus, S., Thyssen, G., Groot, W., \& Maassen van den Brink, H. (2013). A critical review of the literature on school dropout. Educational Research Review, 10, 13-28.

De Witte, K. \& Csillag, M. (2014). Does anybody notice? On the impact of improved truancy reporting on school dropout. Education Economics, 22(6), 549-568.

Dowrick, P. W. \& N. Crespo (2005), School failure. In T. P. Gullotta, \& G. R. Adams (Eds.), Handbook of adolescent behavioral problems: Evidence-based approaches to prevention and treatment (pp.589-610). New York: Springer Science and Business Media. 
Entwisle, D. R., Alexander, K. L., \& Steffel-Olson, L. (2004). Temporary as compared to permanent high school dropout. Social Forces, 82(3), 1181-1205.

European Commission/EACEA/Eurydice/Cedefop (2014). Tackling Early Leaving from Education and Training in Europe: Strategies, Policies and Measures. Eurydice and Cedefop Report. Luxembourg: Publications Office of the European Union.

Hattie, J., (2009). Visible Learning: A Synthesis of over 800 Meta-analyses relating to achievement. London: Routledge.

Herbert, T. P., \& Reis, S. M. (1999). Culturally diverse high-achieving students in urban high school. Urban Education, 34(4), 428-457.

Ivić, I. (2014). Vygotsky's Theory and some Variants of Post-Vygotskyan Theories and their Implications for Didactic Interaction in the Inclusive School. In B. H. Johnsen (Ed.) Theory and Methodology in International Comparative Classroom Studies (pp. 69-81). Oslo: Cappelen Damm AS.

Kovač-Cerović, T., Jovanović, O. and Pavlović-Babić. D. (2016). Individual education plan as an agent of inclusiveness of the educational system in Serbia: Different perspectives, achievements and new dilemmas. Psihologija, 49(4), 431-445.

Lee, F., W-L., and Ip, F. M-L. (2003). Young School Dropouts: Levels of Influence of Different Systems. Journal of Youth Studies, 6(1), 89-110.

Lyche, C. (2010), Taking on the Completion Challenge: A Literature Review on Policies to Prevent Dropout and Early School Leaving, OECD Education Working Papers, No.53, OECD Publishing.

Ministry of Education, Science and Technological Development Republic of Serbia, Social Inclusion and Poverty Reduction Unit and UNICEF (2014). POLICY IMPACT ANALYSIS: Providing Additional Support to Students from Vulnerable Groups in Pre-University Education. Retrieved from web site: https://www.unicef.org/serbia/POLICY-IMPACT-ANALYSIS-Providing-Additional-Support-toStudents-from-Vulnerable-Groups-in-Pre-University-Education.pdf

Periata, C. \& Pastor, M. (2000). The Primary School Dropout in Spain: The Influence of Family Background and Labor Market Conditions. Education economics, 8(2), $157-168$.

Rado, P. (2010). School Failure in Serbia. Psihološka istraživanja, 13(1), 59-90.

Rumberger, R. (1983). Dropping out of high school: The influence of race, sex, and family background. American Educational Research Journal, 20(2), 199-220.

Rumberger, R. (1987). High School Dropouts: A Review of Issues and Evidence. Review of Educational Research, 57(2), 101-121.

Rumberger, R. (2011). Dropping Out: Why Students Drop Out of High School and What Can Be Done about It. Cambridge, MA, USA: Harvard University Press.

Simić, N. and Krstić, K. (2017). School factors from primary and secondary education in Serbia - qualitative research. Psihološka istraživanja, 20(1), 51-70.

Službeni glasnik Republike Srbije. (2012). Razvoj obrazovanja u Srbiji do 2020. godine. Broj 107. In Serbian. (The Official Gazette of the Republic of Serbia. Development of Education in Serbia until 2020. No. 107).

Službeni glasnik Republike Srbije (2013). Zakon o srednjem obrazovanju. Broj 55. In Serbian (The Official Gazette of the Republic of Serbia. Law on secondary education. No. 55). 
Službeni Glasnik Republike Srbije (2013a). Jedinstvena lista razvijenosti regiona i jedinica lokalne samouprave. Broj 62. In Serbian. (The Official Gazette of the Republic of Serbia. A unique list of the development of the region and municipalities. No. 62).

Službeni glasnik Republike Srbije (2015a). Pravilnik o kriterijumima i standardima za finansiranje ustanove koja obavlja delatnost osnovnog obrazovanja i vaspitanja. Broj 36. In Serbian. (The Official Gazette of the Republic of Serbia. Regulations regarding criteria and standards for financing an institution within primary education. No. 36).

Službeni glasnik Republike Srbije (2015b). Pravilnik o kriterijumima i standardima za finansiranje ustanove koja obavlja delatnost srednjeg obrazovanja i vaspitanja. Broj 75. In Serbian (The Official Gazette of the Republic of Serbia. Regulations regarding criteria and standards for financing an institution within secondary education. No. 75).

Statistički godišnjak (2014). Repiblički zavod za statistiku, Republika Srbija. (Statistical yearbook, 2014. Statistical Office of the Republic of Serbia). Retrieved from the web site: http://pod2.stat.gov.rs/ObjavljenePublikacije/G2014/pdfE/ G20142013.pdf

Stepanović Ilić I., Videnović, M., and Lazarević, Lj. (2015). Odustajanje od školovanja - analiza studija slučaja iz ugla ekološkog pristupa. Nastava i vaspitanje, 64(3), 383-406. (Leaving school: Analysis of a case study from the angle of the ecological approach)

UNICEF (2014). Best of UNICEF Research 2014. Florence: UNICEF Office of Research. Retrieved from the web site: https://www.unicef-irc.org/publications/ pdf/bour2014.pdf

\title{
Socijalni faktori van porodice i škole povezani sa osipanjem
}

\section{Ivana Stepanović Ilić}

Univerzitet u Beogradu, Filozofski fakultet, Institut za psihologiju

\section{Ljiljana B. Lazarević}

Univerzitet u Beogradu, Filozofski fakultet, Institut za psihologiju

\section{Nataša Simić}

\author{
Univerzitet u Beogradu, Filozofski fakultet
}

Rad prikazuje sistematizaciju širih socijalnih faktora koji doprinose ospipanju u Srbiji iz prespektive Bronfenbrenerovog pristupa. Iako su ovi faktori prepoznati u literaturi i obično povezivani sa zajednicom i obrazovanjem kao sistemom (community and systemic factors), retko su istraživani. Dodatnu inspiraciju predstavlja naše prethodno istraživanje osipanja na studijama slučaja koje se dominan- 
tno bavilo porodičnim i školskim faktorima takođe iz ekološke perspektive. Podaci su dobijeni putem polustrukturiranih intervjua sa sledećim grupama ispitanika (uključujući i analizu dostupnih relevantnih ststistsičkih podataka): učenici koji su napustili školu ili su pod rizikom i nihovi roditelji; direktori, psiholozi i pedagozi iz škola sa visokom i niskom stopom osipanja; predstavnici nastavnika, roditelja i učenika iz škola sa visokom stopom osipanja; socijalni radnici zaduženi za škole sa niskom stopom osipanja, predstavnici nacionalnih obrazovnih institucija. Rezultati pokazuju dominaciju faktora sa negativnim uticajem na školovanje dece nad podsticajnim, koji bi mogli prvenetivno delovati na osipanje. Deformativni uticaji postoje u svim socijalnim nišama: u mikrosistemima (vršnjaci skloni rizičnom ponašanju i siromašno susedstvo), u slabim mezosistemskim vezama škole i porodice sa lokalni institucijama, u egzositemima (nerazvijene regije) do nivoa makrosistema (neefikasna zakonska regulativa, nepovezanost obrazovnih institucija i vladinih resora). Formativni uticaji uočeni su u mezosistemskim vezama škola koje su primer dobre prakse, kao i na nivou makrosistema u vidu prepoznavanja problema osipanja na nacionalnom nivou. Iako preliminarni, dobijeni rezultati predstavljaju korisne i važe smernice za buduća istraživanja.

Ključne reči: osipanje, širi socijalni faktori, kvalitativna analiza podataka, pozitivni i negativni uticaj unutar različitih ekoloških niša 